\title{
The Anticipation of Working Experiences among Students from Private Institutes in Klang Valley: A Qualitative Perspective
}

\author{
${ }^{a}$ Kyra Law Ley Sy, ${ }^{b}$ Kue Wei Xin \\ ${ }^{a, b}$ School of Management and Marketing, Faculty of Business and Law, Taylor's University, \\ 47500 Subang Selangor, Malaysia \\ Corresponding Author: kyraleysy.law @ taylors.edu.my
}

To cite this article (APA): Law, K., \& Kue, W. X. (2020). The anticipation of working experiences among students from private institutes in Klang Valley: A qualitative perspective. International Business Education Journal, 13(1), 60-70. https://doi.org/10.37134/ibej.vol13.1.5.2020

To link to this article: https://doi.org/10.37134/ibej.vol13.1.5.2020

\begin{abstract}
As university students are entering a competitive workforce, getting a desirable job has become more demanding. Many universities offer industrial training or internship placements in their degree programmes. Thus, this study provides a qualitative perspective of anticipation of working experiences among university students in Klang Valley. This study is carried out in the form of face-to-face semi-structured interviews with ten university students in Klang Valley. The contents are analyzed by its content and code in themes. The results show that the anticipations of working experiences among university students fall into a few categories which are; relevant education, purposes and importance of working experiences as well as the challenges faced in the workforce. This study closes the gap between workforce expectation and students' impractical expectations as it gives university students a better insight about working experience especially during their studies so that they can pre-plan their future. Overall, this study can benefit future university students by improving their expected skills which will lead to higher employers' satisfaction.
\end{abstract}

Keywords:

Working experiences, anticipation, university students, private universities, Klang Valley

\section{INTRODUCTION}

The report of Recent Development of International Higher Education in Malaysia in 2018, there is a significant increase in the number of university students from 1.25 million in the year 2017 to 1.30 million students in the year 2018 enrolling into sandwich courses in Malaysia. Sandwich courses are identified as courses that offer industrial training or internship placements where university students will be required to participate in during their undergraduate programmes (Jackson and Wilton, 2017; Davies and Stamford, 2014; Blackwell et al, 2001). These courses give chances of getting a desirable job to rely on the opportunities to relevant working experiences. Similarly, employers will prefer university students with working experiences rather than those without working experiences (Belwal, Priyadarshi \& Al Fazari, 2017). Past research stated that 31 per cent of employers emphasized the importance of having working experiences among university students in the efforts to prepare them for the actual first job (Sarkar et al., 2016). Significantly, working experiences play an essential role in employee recruitment since 
the selection of fresh graduates has substantial effects on an organization. Due to the increasing number of graduates, employers are bound to demand working experiences regardless of the need for qualification for job positions (Chamorro-Premuzic \& Frankiewicz, 2019). Thus, the objective of this study is to explore the perception of working experiences among university students in Klang Valley.

\section{LITERATURE REVIEW}

Working experience refers to the extent to which executives have amassed varied levels of roles and responsibilities in the key work activities which individual encounter throughout their careers (Dragoni et al, 2011). For fresh graduates, working experience is also defined as the experiences that one has obtained in a workplace during their journey of pursuing education or before starting their career pathway (Blackmore, Gribble \& Rahimi, 2017). The empirical evidence exists of work experience related to one's academic field increasing students' grade point average (Tuononen et al, 2016). Therefore, relevant work experience during a degree programme has a larger positive effect on employment as these work experiences bridge the divide that is already present (Moores, Birdi \& Higson, 2017). However, there is an increase in a mismatch between a person's field of study and their occupations.

According to Blicblau, Nelson \& Dini (2016), one can achieve working experience through industry-based-learning (IBL) which is known as co-operative education, sandwich year, or work-integrated learning. IBL provides students with the opportunity to undertake a paid, relevant work placement as part of their university degree (Rajibussalim, Sahama \& Pillay, 2016). Non-placement IBL, such as industry-based projects and simulations, connects students with industry in an authentic learning experience in a campus setting. Work placement or internship is a characteristic of contemporary higher education which is focused towards improving the development of students' employability and transferable skills (Jones, Green \& Higson, 2017). An internship is supervised introductory career opportunities provided in partnership between academic institutions and professional organizations (Sides \& Mrvica, 2017). In Malaysia, working experience is steered full time and it comprises of industrial training, internship, work placement and practicum.

Employers expect a student to be equipped with working experience before they start on their career. Employers assume that university students are furnished with working experience as most of the courses in the university include an internship or work placement as a compulsory component for students to complete internships and work placement before graduating (Hassan, 2018). Similarly, university students may go extra miles of getting working experiences to differentiate themselves among others as labour market for graduates is highly competitive (Jackson \& Collings, 2018; Hassan, 2018; McMurray et al, 2016). It is proven in past studies that students with work placements experiences appear to have improved performance and more driven to succeed (Ceschin, Rakowski \& de Vere, 2017; Jones, Green \& Higson, 2017).

Other than to gain real working experience, students able to explore their own identities, social roles, develop skills that are not as theories and confirming on strengths and skills to invest in (Koenig \& Guertler, 2018; Belwal, Priyadarshi \& Al Fazari, 2017; Jackson \& Wilton, 
2017; Brooks \& Youngson, 2016; Gbadamosi et al, 2015; Monteiro \& Almeida, 2015). The skills include communication, teamwork, and interpersonal relations and enhanced project management and implementation skills (Blicblau, Nelson \& Dini, 2016). University students prepare themselves with working experiences so that they can adapt in their new environment easily (Ceschin, Rakowski \& de Vere, 2017). As such, students may undergo an easier transition from a university to their first job (Flint \& Agarwal, 2018; Hamilton et al, 2018; Sarkar et al, 2016; Monteiro \& Almeida, 2015) as they can practice by applying skills and knowledge gained from their previous working experiences (Jackson \& Collings, 2018; O'leary, 2017; Matsouka \& Mihail, 2016; McMurray et al, 2016). Additionally, having enough working experience may also assist university students in career planning and decision-making process (Hamilton et al, 2018; McGrath \& Murphy, 2016). Hence, this study identifies and explores students' expectation and anticipation of getting a work placement before they enter the marketplace.

Past studies indicate that obtaining working experiences however may be challenging for students due to unfavourable working environment (Tran \& Soejatminah, 2017). According to Jackson (2015), students may experience difficulties with articulating their viewpoints, instructions and responses to different audiences in the workplace and sometimes struggle to engage others to make their voice heard. Students may feel isolation and inadequacy in working with experienced and confident co-workers. Students may have a negative perception towards a certain industry which is one of the unfavourable impacts of working environments (Tan et al, 2016).

Additionally, insufficient resources to coordinate work placements, especially the supervision of students while in the workplace (Jackson et al, 2017). The lack of work placement opportunities may cause by a misalignment between employer and university expectations in terms of the purpose and nature of the work placement. According to Barnhardt et al (2019) and Muluk (2017), excessive working hours for students may contribute to working experience; however, it may also affect their academic success as well. Time spent on working part-time jobs is more than studying leads to less focus on studies. It has also been found that working students are potentially to achieve lower grades than non-working students (Tuononen et al, 2016). Working experiences is becoming one of the main factors when it comes to recruiting and hiring university graduates; however, many are still unaware of the importance and benefits of having working experiences. This may cause them to miss the opportunity to secure a good job.

\section{METHODOLOGY}

A research methodology indicates a model to establish research within the framework of a paradigm that encompasses sets of belief (Wahyuni, 2012). The adoption of qualitative technique in this research is to go beyond ordinary explanation at a generalizable level (Neergaard \& Ulh, 2007) and discover answers to research question through the application of systematic procedures (Berg \& Lune, 2013). A handful of qualitative researchers consider qualitative research is the unsurpassed way to understand a phenomenon in its context (Krauss, 2005). The inductive approach is utilized when data collection is analyzed to observe some patterns that emerge to suggest a relationship between variables (Gray, 2009). This qualitative study allows researchers to better understand human conditions and the perceived situation in a different 
context, which enhances and monitors the credibility of the study (Bengtsson, 2016). Researchers move towards discovering a binding principle and it attempts to establish patterns, consistencies and meanings through the process of gathering data.

The purposive sampling method is utilized to find out the perception of working experience among university students. It is categorized under the non-probability sampling technique where it states that it is an intentional choice of the respondent due to the qualities and traits that they possess (Etikan, Musa \& Alkassim, 2016). The purposive sampling method allows the researchers to control and restrict the selected sample to categorize university students in Klang Valley. In this case, the purposive sampling method is applicable as the study focuses on university students with some working experiences and located in Klang Valley.

The sample population is chosen as these students have prior working experiences before their first job in the workplaces. The sample size is determined by the saturation of the information given by the respondents (Alvi, 2016). They can provide insights about their real-life experiences and challenges that are faced during their placements. The researchers work with ten undergraduate students who come from different universities in Klang Valley. The targeted respondents are chosen based on the same characteristics; which is having working experiences before graduating. Consequently, ten respondents are involved in this research to provide rich content and information that is needed for the study.

The face-to-face semi-structured interviews last for an average of 15 to 20 minutes and recorded on audio for research purposes. The data is also transcribed in text format to ensure consistency. The data is then analyzed using Nvivo 12 which the researchers generate themes according to the data provided by the respondents. Thematic analysis can be broken down into six steps which are, transcribe, coding, generating, reviewing, defining and writing (Terry et al, 2017).

\section{RESULTS AND DISCUSSION}

Table 1: Respondents' demographic profile

\begin{tabular}{ccccc}
\hline Respondents & Age & Course & Gender & $\begin{array}{c}\text { Working } \\
\text { experiences }\end{array}$ \\
\hline Respondent 1 & 21 & Accounting and Finance & Male & Yes \\
Respondent 2 & 21 & Accounting and Finance & Male & Yes \\
Respondent 3 & 21 & Economics and Finance & Female & Yes \\
Respondent 4 & 22 & International Business and Marketing & Male & Yes \\
Respondent 5 & 20 & Marketing & Male & Yes \\
Respondent 6 & 21 & Marketing & Female & Yes \\
Respondent 7 & 21 & Business & Male & Yes \\
Respondent 8 & 22 & Marketing & Female & Yes \\
Respondent 9 & 22 & Finance & Male & Yes \\
Respondent 10 & 22 & Law & Female & Yes \\
\hline
\end{tabular}


Ten respondents age between 20 to 22 years old are interviewed regarding their perception and views about having working experiences. These respondents come from different universities and study in various courses (Table 1). Three themes are generated from the interviews; education relevancy, purposes and importance of working experiences and challenges faced in Figure 1.

\section{Education relevancy}

The education relevancy refers to the education background that related to workplace tasks. 50 per cent of the respondents stated that having a working experience that is related to their studies allow them to enhance their skills before going into the workforce. Respondent 1 states that he can try out new things and develop new skills in the audit firm. At the same time, he can juggle more responsibilities that are given at his audit intern position. He said that 'It kind of taught me on how to be more careful and taught me on interpersonal skills and how should I communicate with my manager to somehow convey the messages I want to bring and also to understand the task that I am given to do.' Respondent 3 confirms that working as an intern in an investment company allows her to enhance various skills like leadership and presentation skills. She said that 'I will say that it gave me the experience whereby I can learn different skill sets such as leadership skills, presentation skills, communication skills, critical thinking and problemsolving.' However, Respondent 8 thought that one of the technical skills that she can develop is her marketing skills which are not taught during her university days. She claims that 'Though I'm a marketing major, I will say performance marketing is one of the key major skills set that I have learnt during my work placement.'

Having work experience that is relevant or related to university students' education helps students to have a better preparation before embarking their journey on their career path. Respondent 7 states that the reason he works for Petronas is due to the similar job scope that he will want to venture in the future, 'It will be better if you work somewhere within the same job scope as to what you want in future. I feel like that will help more rather than just working anywhere like a job that you can get easily but somehow not related to your future job scope.' This is confirmed by Respondent 10 who said that 'I will say working in a relevant industry is useful because that's how you build a foundation in a certain industry.'

Other than that, relevant working experiences will increase and improve their personal growth in a career path to reduce a mismatch between the field of study and their occupations. Respondent 6 describes that although having a working experience that may be irrelevant to ones' education, it can boost a person's personal growth. The individual will gain an advantage over the other graduates with better capabilities or skills that other graduates do not possess. Respondent 7 seconds the idea by saying 'It doesn't matter, any industry will be fine as long as you like what you are doing, and you learn something from it.' The focus is on personal growth that might contribute to one's future.

Purposes and importance of working experiences

Most employers expect their employees to be equipped with working experiences before they take up the job. Thus, personal development has become one of the most important purposes for 
university students to get working experiences. Respondent 1 reveals that he wants to have working experience because it helps him to recognize his strengths and weaknesses This allows him to make better decisions when he goes to the workforce in future. He said that 'I want to be able to learn something before I go into the real working environment.' Respondent 4 also expresses that he will want to acquire different experiences which he will be able to better identify his career path. He said that 'I want to be exposed to a more structured learning environment whereby I can do meaningful work.'

Although personal development is one of the crucial aspects, monetary rewards come next. Among the ten respondents, four respondents have claimed that monetary rewards are equivalently essential. Respondent 10 claims that 'As a student, for me, I don't want to depend on my parents to get money. Well, it's not like sometimes you need the money, it's because you want extra to save to buy the things that you want.' These students opt to work because they have free time during holidays, and they do not want to waste time by doing anything. Consequently, instead of staying at home, they decide to work and earn extra income. Respondent 6 confirms 'I don't want to waste my semester break and 3 months is a long time, I don't know what to do with it. And I thought might as well earn an extra income and at the same time do something with the time given.'

Taking up work placements during university days has helped many students to be better decision-makers. Respondent 2 mentions that with the various experience that he has gained through his working experience, he can attain better decision making in future. He said that 'Insights that you will only be able to deem when you are working within that environment itself and it's not something you can research online.' Respondent 4 further seconds the statement, 'Having working experiences, one will be able to gain insights about the working environment that is unattainable from textbooks which a better decision making is done.'

The importance of having working experience will give one different exposure where they learn the etiquette to communicate to different stakeholders. This is aligned with the previous study which states that communication, teamwork, and interpersonal relations and enhanced project management and implementation skills are essential in the workplace (Blicblau, Nelson \& Dini, 2016). Respondent 3 expresses, 'It teaches me on how to be more careful and taught me on interpersonal skills and how should I communicate with my manager to somehow convey the messages I want to bring and also to understand the task that I am given to do. 'Working experiences has facilitated Respondent 3's interpersonal skills and understanding to communicate with her managers. Similarly, Respondent 6 is more confident to speak to external parties. She further explains she can leverage past experiences during her interview.

When it comes to gaining working experience, Respondent 5 emphasizes the importance of gaining credentials as he also mentions that both his working experiences are unpaid. He stresses the fact that credentials matter than just focusing on monetary rewards. He further elaborates that credentials come in the form of endorsements and offer letters. He said that 'I can gain credentials and being recognized by corporate.' Similarly, Respondent 9 states that working experience is a form of attaining credentials because it is a form of recognition too. He also expresses that 'I think it will help to boost my resume as well.' 


\section{Challenges faced}

Excessive working hours for students may affect their academic success (Barnhardt et al, 2019; Muluk, 2017). As a university student, needing to work after school hours is a challenge for students. Respondent 1 states that time constraint became of his challenge while working where he was not able to spend extra time on other activities. He further explains that working while studying is stressful as he must juggle both his time and responsibility as a student and worker. He said that 'As a student, I think it is very stressful because you have to juggle your time and your responsibilities.' However, respondent 9 comments about students who are working while studying may not be keen to work beyond their studying hours due to the time constraint.

Likewise, students who are working might face a lack of focus when it comes to studying. 'Some of us can't balance between studies and work, some focus more on our jobs rather than studies', said Respondent 1. A similar challenge faced by Respondent 5, some students are engrossed with working and they do not focus on studies. He expresses that 'Students are not paying attention to whatever is going around now.' Respondent 9 claims that students think working takes a toll on them due to different activities at the same time. Correspondingly, Respondent 7 elaborates that he is unsure if he can handle the stress of working as a student. He further explains that he must travel to work after classes and work for 3 to 4 hours each time. 


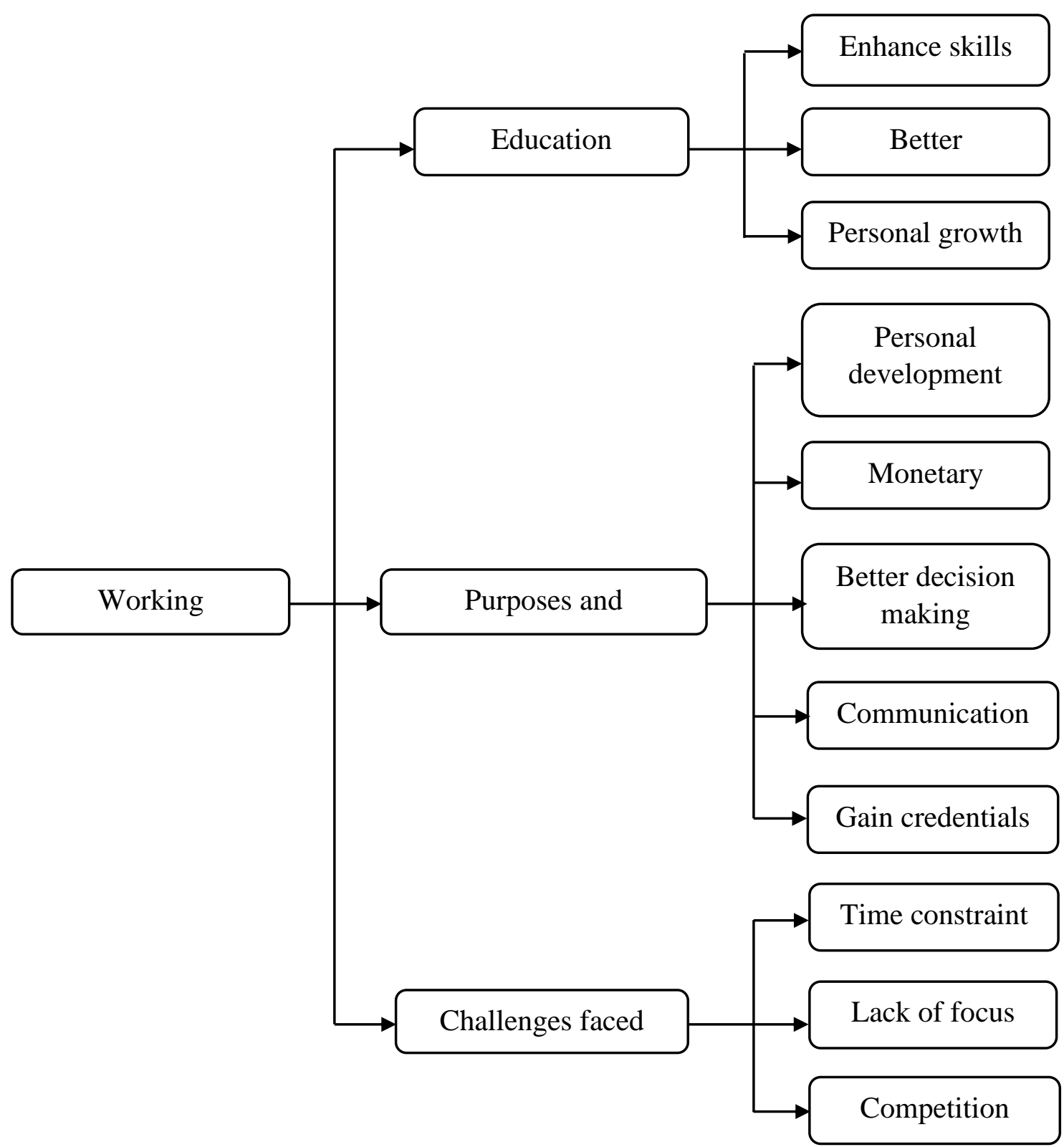

Figure 1: Coding hierarchy

Moreover, competition in landing to a desirable job is rather difficult due to an increasing number of graduates. Respondent 5 expresses, 'Now the industry is much more competitive than we expect.' It is also difficult for university students or graduates to get a placement in a company that is reputable in an industry as tight competition for university students to get a job is critical. This also causes Respondent 6 to feel that she is not good enough though she has different working experiences in various fields. This has supported the literature of students experiencing difficulties to articulate their viewpoints, instructions and responses to different audiences in the workplace and sometimes struggle to engage others to make their voice heard (Jackson, 2015). 


\section{CONCLUSION}

The study starts by identifying the problems university students are having now in a marketplace; such as, unaware of the importance of working experiences, lack of employability skills, mismatch to jobs and career choosiness. Almost half of the respondents mention that their education is to enhance their skills for the future. Seven respondents out of ten said the purpose and importance of working experience among students are to have personal development and improve communication skills. However, respondents are also facing challenges such as time constraint and competition to secure a work placement.

This study serves as a guide for future university students as it includes the details of working experiences (i.e education relevancy, purposes and importance of working experiences and challenges faced). Graduates can potentially reduce the number of 'mismatches' between their expectation and reality as well as between education and career choice. The findings of this study give students a better insight about having working experience especially during university days which they can plan for their future. Thus, it will lead to better satisfaction of employers towards employees. The compilation of the transcripts from various private universities in Klang Valley allows universities to analyse the strengths and weaknesses when it comes to work placements for students. The data is helpful to companies as it provides insights on what students perceive about bigger and reputable companies.

\section{REFERENCES}

Alvi, M., (2016). A manual for selecting sampling techniques in research. Munich Personal RePEc Archive. Retrieved from: https://mpra.ub.uni-muenchen.de/70218/

Barnhardt, C.L., Trolian, T., An, B., Rossmann, P.D. \& Morgan, D.L., (2019). Civic learning while earning? The role of student employment in cultivating civic commitments and skills. The Review of Higher Education, 42(2), 707-737.

Belwal, R., Priyadarshi, P. \& Al Fazari, M.H., (2017). Graduate attributes and employability skills: Graduates' perspectives on employers' expectations in Oman. International Journal of Educational Management, 31(6), 814-827.

Bengtsson, M., (2016). How to plan and perform a qualitative study using content analysis. NursingPlus Open, 2, 8-14.

Berg, B. L., \& Lune, H. (2013). Qualitative study methods for the social sciences (Vol. 8). Boston, MA: Pearson.

Blackmore, J., Gribble, C. \& Rahimi, M., (2017). International education, the formation of capital and graduate employment: Chinese accounting graduates' experiences of the Australian labour market. Critical Studies in Education, 58(1), 69-88.

Blackwell, A., Bowes, L., Harvey, L.E.E., Hesketh, A.J. \& Knight, P.T., (2001). Transforming work experience in higher education. British Educational Research Journal, 27(3), 269-285.

Blicblau, A.S., Nelson, T.L. \& Dini, K., (2016). The Role of Work Placement in Engineering Students' Academic Performance. Asia-Pacific Journal of Cooperative Education, 17(1), 31-43.

Brooks, R. \& Youngson, P.L., (2016). Undergraduate work placements: an analysis of the effects on career progression. Studies in Higher Education, 41(9), 1563-1578.

Ceschin, F., Rakowski, R. \& de Vere, I., (2017). The influence of work placement on the academic achievement of undergraduate design students. The Design Journal, 20(2), 259-278. 
Chamorro-Premuzic, T., \& Frankiewicz, B. (2019). Does Higher Education Still Prepare People for Jobs? Retrieved from: https://hbr.org/2019/01/does-higher-education-still-prepare-people-forjobs

Davies, H.M. \& Sandiford, P.J., (2014). Legitimate peripheral participation by sandwich year interns in the national health service. Journal of Vocational Education \& Training, 66(1), 56-73.

Dragoni, L., Oh, I.S., Vankatwyk, P. \& Tesluk, P.E., (2011). Developing executive leaders: The relative contribution of cognitive ability, personality, and the accumulation of work experience in predicting strategic thinking competency. Personnel Psychology, 64(4), 829-864.

Etikan, I., Musa, S. A., \& Alkassim, R. S. (2016). Comparison of convenience sampling and purposive sampling. American Journal of Theoretical and Applied Statistics, 5(1), 1-4.

Flint, C. \& Agarwal, J., (2018). An investigation into the experience of advertising students in seeking and working in internships. Journal of Innovation in Polytechnic Education, 1(1).

Gbadamosi, G., Evans, C., Richardson, M. \& Ridolfo, M., (2015). Employability and students' part-time work in the UK: does self-efficacy and career aspiration matter? British Educational Research Journal, 41(6), 1086-1107.

Gray, D. E. (2009). Doing study in the real world. Sage.

Hamilton, K., Morrissey, S.A., Farrell, L.J., Ellu, M.C., O'donovan, A., Weinbrecht, T. \& O'connor, E.L., (2018). Increasing Psychological Literacy and Work Readiness of Australian Psychology Undergraduates through a Capstone and Work-Integrated Learning Experience: Current Issues and What Needs to be Done. Australian Psychologist, 53(2), 151-160.

Hassan, A., (2018). Internship Framework Guidelines for Malaysian Public Higher Education Institutes. Journal of Science, Technology and Innovation Policy, 4(1).

Jackson, D. \& Collings, D., (2018). The influence of work-integrated learning and paid work during studies on graduate employment and underemployment. Higher Education, 76(3), 403-425.

Jackson, D. \& Wilton, N., (2017). Perceived employability among undergraduates and the importance of career self-management, work experience and individual characteristics. Higher Education Research \& Development, 36(4), 747-762

Jackson, D., (2015). Employability skill development in work-integrated learning: Barriers and best practice. Studies in Higher Education, 40(2), 350-367.

Jones, C.M., Green, J.P. \& Higson, H.E., (2017). Do work placements improve final year academic performance or do high-calibre students choose to do work placements? Studies in Higher Education, 42(6), 976-992.

Koenig, E. \& Guertler, K., (2018). PARLAYING STUDENTS'WORK EXPERIENCE INTO PRACTICE-ORIENTED ESP. Journal of Teaching English for Specific and Academic Purposes, 277-284.

Krauss, S. E. (2005). Study paradigms and meaning making: A primer. The Qualitative Report, 10(4), 758-770

Matsouka, K. \& Mihail, D.M., (2016). Graduates' employability: What do graduates and employers think? Industry and Higher Education, 30(5), 321-326.

McGrath, D. \& Murphy, D., (2016). Understanding accounting as a career: An immersion work experience for students making career decisions. Accounting Education, 25(1), 57-87.

McMurray, S., Dutton, M., McQuaid, R. \& Richard, A., (2016). Employer demands from business graduates. Education+ Training, 58(1), 112-132.

Monteiro, S. \& Almeida, L.S., (2015). The relation of career adaptability to work experience, extracurricular activities, and work transition in Portuguese graduate students. Journal of Vocational Behavior, 91, 106-112.

Moores, E., Birdi, G.K. \& Higson, H.E., (2017). Placement work experience may mitigate lower achievement levels of black and Asian vs. white students at university. Frontiers in psychology, 8,1518 . 
Muluk, S., (2017). Part-Time Job and Students' Academic Achievement. Jurnal Ilmiah Peuradeun, 5(3), 361-372.

Neergaard, H., \& Ulh, J. P. (Eds.). (2007). Handbook of qualitative study methods in entrepreneurship. Edward Elgar Publishing.

O'Leary, S., (2017). Graduates' experiences of, and attitudes towards, the inclusion of employabilityrelated support in undergraduate degree programmes; trends and variations by subject discipline and gender. Journal of Education and Work, 30(1), 84-105.

Rajibussalim, R., Sahama, T. \& Pillay, H., (2016). Realisation of university-industry collaboration through industry-based learning at Indonesian higher education. INTED2016 Proceedings, (2340-1079), 3853-3863.

Sarkar, M., Overton, T., Thompson, C. \& Rayner, G., (2016). Graduate employability: Views of recent science graduates and employers. International Journal of Innovation in Science and Mathematics Education (formerly CAL-laborate International), 24(3).

Sides, C. \& Mrvica, A., (2017). Internships: Theory and practice. Routledge.

Tan, Z.M.A., Baharun, N., Wazir, N.M., Ngelambong, A.A., Ali, N.M., Ghazali, N. \& Tarmazi, S.A.A., (2016). Graduates' perception on the factors affecting commitment to pursue career in the hospitality industry. Procedia-Social and Behavioral Sciences, 224, 416-420.

Terry, G., Hayfield, N., Clarke, V. \& Braun, V., (2017). Thematic analysis. The Sage handbook of Qualitative Research in Psychology, 17-37.

Tran, T.T., (2015). Is graduate employability the 'whole-of-higher-education-issue'? Journal of Education and Work, 28(3), 207-227.

Tuononen, T., Parpala, A., Mattsson, M. \& Lindblom-Ylänne, S., (2016). Work experience in relation to study pace and thesis grade: investigating the mediating role of student learning. Higher Education, 72(1), 41-58.

Wahyuni, D. (2012). The study design maze: Understanding paradigms, cases, methods and methodologies. Journal of Applied Management Accounting Study, 10(1), 69-80. 